\title{
Digital Transformation of the Greek Retail Banking: An Evaluation of Systemic Banks’ Websites
}

\author{
John Mylonakis \\ Financial Services Expert, Athens, Greece \\ E-mail: imylon@otenet.gr
}

Received: Nov. 21, 2018 Accepted: Dec. 4, 2018 Published: December 24, 2018

doi:10.5296/bms.v9i2.14100 URL: https://doi.org/10.5296/bms.v9i2.14100

\begin{abstract}
Digital transformation seems to have been materialized to a large extent by Greek Banks, which continue to innovate in Retail Banking continuously improving their websites and customer choice options. It is important to mention that the Banking sector in Greece has gone on the same footing as banks abroad and is barely able to provide services and services, despite the adverse economic conditions. The paper examines the advantages, disadvantages and the role of the various factors that generally apply to the digital transformation of the Banking Sector. The research revealed that the banking sector in Greece seems to have followed the worldwide technological developments and has made the necessary changes to turn any digital achievements into its own benefit.
\end{abstract}

Keywords: Digital transformation, Web Banking, Retail Banking, Bank cards, Credit Institutions, Information Technology, Banks’ Websites, Financial Services 


\section{Introduction}

Digital Transformation is defined as the creation of digital pathways for the completion of the processes used in the daily production process whatever its form, but also for the digitization of the services provided by an organization (https://en.wikipedia.org/wiki/Digital_transformation).

Digital is called because several electronic media are used, as PC, mobile, or PC applications, robotics etc. Therefore, a manual or documentary process and a physical presence of an employee or client of the business is now done through an electronic form or device such as Web Banking instead of a visit in a bank store.

Transformation is called why it undertakes to transform an existing process from manual/handwritten to digital, from physical to digital, following gradual and steady steps. The areas and activities that can be digitized in a business are in its internal environment and abroad.

Based on the above, two are the main points that help a business transform its processes and services and naturally achieve a digital transformation effort. The first is technology and its application to the widest range of processes (internal or external) and the second is the continuous updating and searching for innovative solutions from the rest of the market or from its workplace, through consultations and studies of employees and its executives. The first is obvious, as digitization without technology is impossible, but the second, because innovation usually brings profit (of any form not only monetary) to many levels in its application. The processes through which Digital Transformation can be applied to a company/bank focus on a) internal procedures. It is the procedures used to co-operate parts of the business with each other or independently and b) its external processes. They relate to processes, products, services involving third parties outside the enterprise and the state.

The way in which Digital Transformation is applied in practice goes through a cycle of 3 main stages (http://www.seidor.com/content/seidor-com/en/digital/metodologia.html):

(1) Feasibility study on the process to be transformed through digital transformation: At this stage, all the information is gathered, the basic need is recognized, what will benefit and to what extent the enterprise. It examines in detail the current situation, how and at what points it will change.

(2) Implementing the Process Transformation Requirements: All that is needed is to implement digital practice. Training, purchase of materials, necessary updates to the organization's systems and so on.

(3) Applying the transformation and replacing the old mechanism: At this stage, the business is now working in the new way and the model is tracked for any improvements and profit gained so that it can be reused for replenishment to any other change.

\section{Factors Influencing the Implementation of Digital Transformation}

The factor or factors that affect digital transformation during its implementation are 
summarized in the development of Technology, the introduction of Innovation, the quality of Human Resources, the Capital and the role of the State (Papadimitriou, 2018). The main advantages of digital transformation are:

- Increased efficiency in the day-to-day operation of the business.

- Enhanced decision making by the relevant executives.

- Increase of the Company's Clients 'Clients' Portfolio and / or adjustment of their Customer base and receivables.

- Increase in profit margin through the reduction of operating costs. And the

- Increased Customer Satisfaction through extended hours and ways to meet its needs.

The common denominator of all the above advantages is the simplification and the reduction of the time of each process that participates in the business piece being transformed. A downside can be the decline in Human Resources due to process and service optimization. However, this is controversial because it is not exclusively digital transformation but is essentially a result of the application of technology. Would the reduction in staff be offset perhaps by the need for more technically trained employees, as in the IT departments of the company or by the possibility of training on new technologies and applications?

Another side disadvantage is that where there is much technology, digital fraud spreads. New cheating techniques appear, and as far as digital deployment is concerned, the more the risk of deception grows internally in the company / bank and its customers. Additionally, implementing a malicious design of a digital process can bring lags and extra costs to the business. That is to deduct the advantages which in the right conditions of implementation get the one who applies it, forcing it to undergo a process of reviewing its design.

The adaptation of a process, the creation of a new product, service in digital form or provision requires that attention be given to new points that were not present in manual / handwritten processes. The concepts that are now introduced are Security, Transaction and Transaction Cryptography.

\section{The Digital Transformation in the Banking Sector}

As it can be seen from the advantages, disadvantages and the role of the various factors that generally apply to the digital transformation of a business, the same applies to the Banking Sector and its businesses (Drinkwater, 2016). Here are the factors and how they help in the digital transformation of a Bank:

- Technology: Obviously it is the building block for digital change in one process. Increased use of new technologies in Banks offers comparative advantages because it offers alternatives, increased speed, new capabilities, greater scope for transformation and, of course, greater security, but also due to all the above, perhaps approaching more customer base through new products. 
- Innovation: The creation of innovative banking products and the creation of innovative processes allow a bank to be more receptive to digital transformation. Accepts changes, where a more conservative bank idea may have rejected. So creating an innovation helps digital transformation and the implementation of digital transformation into a bank can lead to innovative products or services.

- Capital: Banks, as the primary money market builder, the more capital they provide the better technology they will buy and more work they will carry out. The natural consequence is to affect the digital transformation in the Banks. Additional capital for staff training in new technologies gives another advantage, since digital transformation usually requires staff to have the latest technology.

- Human resources: as mentioned in the chapter on capital, well-trained staff is key to successfully implementing a digital reform. Typically, in banks each employee has specific applications on his computer. By creating a change in a process that is now digitized, it can affect the performance of its work. Therefore, the opinion of the employee and all those involved in the digital transformation of a process must be considered. A properly trained and well-trained employee will have an even more accurate opinion on the outcome of the actions.

- State: Digital transformation in the banking market requires much more attention to its implementation, since it has to be applied to organizations that move a multitude of sensitive personal data, fortunes and the fate of third-party businesses. It is therefore imperative for any change to be made in its digital format, to ensure that the new procedures are in the process of being required by law, since a person is now required to oversee the Personal Data when the changing process concerns processing of such data, the Bank must comply with the latest European Directive. The proposals must be formulated with the prior opinion of the Personal Data Security Officer. This is because after the final implementation, without his prior opinion, the way in which the digital switchover will take place may have to be redesigned, thus incurring additional time and / or money costs.

New instructions have also been issued to encrypt data and how POSs send data over the communications networks. Therefore, an important branch of transaction security is encryption and accreditation technologies, which cannot, or at least not, ignore a Credit Institution. Whether the transformation involves internal processes of the organization or its external processes, i.e. customer or third-party processes, special attention will be given to security of access to services, encryption and dissemination of information to third parties.

The big difference concerns digital transformation which bring an extra cost to a company that moves money and money and any other business. For example, a bank must provide security for the transaction more than another business with an online store that can manage it for a third party. The bank requires that its web banking be within "IT territory" for obvious reasons (Pwc, 2017). 


\section{Analysis of Digital Benefits in Domestic Banking}

The method used to compile the data and categorize it appropriately so that clear conclusions can be drawn is made using the DEMO versions of E-banking options (Annual Reports Alpha Bank, Eurobank, National Bank, Piraeus Bank) and visit the individual menu of the websites of the four Systemic Banks to collect as much clear material as possible

(http://www.alpha.gr/page/, https://www.nbg.gr/, https://www.eurobank.gr/el/retail, http://www.piraeusbank.gr/el/idiwtes).

The difficulty that occurred was that each bank had a different name for each service it provided in relation to another or had little difference in the way it performed. At the same time, there were names where you should refer to further study on what exactly this service provides - fortunately usually summary - but the information was on every website. The proper definition of the Retail Banking services provided by each bank through its websites highlights a) a proper digitization of its processes; b) its technological upgrading; and c) it has an impact on how this digitalization is emerging. Does it perceive it as a good implementation, as a problem, or helps him to carry out his work?

It is noted that the study of websites does not control whether a Bank is better than another but tries to show the extent to which it has introduced Digital Transformation into its banking processes. One can claim that all Banks have the same functions in Web Banking and offer the same services. However, Digital Transformation is mainly customer-oriented. The Customer must benefit from this and in the second year, through it, the Bank. Thus, a customer who needs a bank three moves to pay in another five, then clearly one of the two has optimized its process.

\subsection{Digitization of Banking Services in Retail Banking}

The main function of Retail Banking is the daily transaction with the public for information, payments, deposits and withdrawals as well as Consumer / Housing Loan. Below, the data from each case study on the use and disposal of Credit Cards and Electronic Banking Transactions are presented per category of control.

\subsection{Issue of Bank Cards}

Table 1. Cards Available for Electronic Transactions

\begin{tabular}{|l|c|c|c|c|c|c|}
\hline & \multicolumn{2}{|c|}{ Kind of Bank Cards } & & \multicolumn{2}{c|}{ Issuer } \\
\hline & Prepaid & Credit & Debit & Solidarity & $\begin{array}{c}\text { AMERICAN } \\
\text { EXPRESS }\end{array}$ & DINERS \\
\hline ALPHA BANK & $\mathrm{X}$ & $\mathrm{X}$ & $\mathrm{X}$ & & $\mathrm{X}$ & $\mathrm{X}$ \\
\hline $\begin{array}{l}\text { NATIONAL } \\
\text { BANK }\end{array}$ & $\mathrm{X}$ & $\mathrm{X}$ & $\mathrm{X}$ & $\mathrm{X}$ & & \\
\hline EUROBANK & $\mathrm{X}$ & $\mathrm{X}$ & $\mathrm{X}$ & & & \\
\hline PIRAEUS BANK & $\mathrm{X}$ & $\mathrm{X}$ & $\mathrm{X}$ & & & \\
\hline
\end{tabular}

Electronic cards were a great way to increase retail banking, mainly due to the time of Capital 
Controls in Greece. Table 1 shows the options available to the four Bank customers for their day-to-day transactions using credit or debit cards. It is noted that all banks offer the same options for using credit, debit and prepaid cards from the same international publishing houses other than American Express and Diners, where Alpha Bank has its exclusive issue.

The Digital Transformation of a Bank with the provision of cards is enhanced as:

1) In the current period, Capital Controls still apply, and many transactions are now made with plastic money.

2) Providing more options per card type and issuer will increase the comparative advantage of the bank.

3) At the same time, it increases the operating costs for technology, as well as commissions to publishers.

4) Because of a variety of options, it may have an unusual clientele compared to another competing credit institution, giving it an advantage.

5) In the case of the Solidarity Cards, which are a special card and its maintenance requires special computer and electronic procedures by the issuer; it must certainly be positively counted in the digital footprint of any credit institution that owns it.

6) Business promotional cards are cards that carry another company's logo for special discounts, but because it concerns electronic payments and digital payments and should therefore be included in the survey.

Therefore, because all the above affect the Bank's technological footprint, and hence its level of digitization, at least to the customer's side, needs to be further analyzed and evaluated.

\subsection{Level of Offered Web Banking Services}

What greatly introduces Banks to digitization and upgrades their image is, above all, the creation and expansion of Web Banking and the services it offers in the case of Retail Banking. The wide range of services and electronic payments that can be processed, as well as the updating and monitoring of additional information regarding their customers, gives banks a big boost to their digital image. This affects the contact with retail customers for the retail segment and the department respectively for businesses. A site may be visually beautiful, but it does not provide anything useful and overly useful to be visually "unobtrusive".

For the modernization, a scale of 0 to 5 (Outdated View ... Modern / Modern Appearance) was enough. The digital image of the Bank is given on two points by the Landing Page and Web Banking (Business and Private) services.

The possibility of payments based on other cards other than their own, but also with or without cards, but with a bank account kept at a rate from 0 to 3, as: 
0 - The Bank does not have such a service on its site.

1 - The Bank allows payment via a current account only

2 - The Bank allows payment via a current account to it and through its own issuance cards

3 - The Bank allows payment by means of an account held therein and through its own issuance cards as well as third Banks.

Accessibility for people with disabilities is also an important part of this, which is of importance when it comes to digital media, calibrated as:

0 - no support,

1 - Support with character and page magnification, support and alternative special colors e.g. for people with color blindness,

2 - Complete support and nomenclature for special page readers for blind people.

It is noted that National Bank of Greece did not have a DEMO at any point, so the analysis was made based on the personal account.

Table 2. Web Banking

\begin{tabular}{|c|c|c|c|c|c|c|c|c|c|c|}
\hline \multicolumn{11}{|c|}{ WEB BANKING - E Banking choices } \\
\hline & $\begin{array}{l}\text { BACKING } \\
\text { IRIS } \\
\text { ONLINE }\end{array}$ & $\begin{array}{l}\text { PAYMENT } \\
\text { VIA MY } \\
\text { BANK }\end{array}$ & $\begin{array}{l}\text { WEB } \\
\text { BANKING } \\
\text { (0..5) }\end{array}$ & $\begin{array}{l}\text { MODERN } \\
\text { LANDING SITE } \\
(0 . .5)\end{array}$ & $\begin{array}{l}\text { STOCK MARKET } \\
\text { ORDERS VIA } \\
\text { WEB BANKING }\end{array}$ & $\begin{array}{l}\text { POSSIBILIT } \\
\text { Y OF WEB } \\
\text { PAYMENT }\end{array}$ & $\begin{array}{l}\text { WEB } \\
\text { BANKING } \\
\text { BUSINESS }\end{array}$ & $\begin{array}{l}\text { SERVICES } \\
\text { SATISFACTIO } \\
\mathrm{N}(0 . .3)\end{array}$ & $\begin{array}{l}\text { DEMO WEB } \\
\text { BANKING } \\
(0 . .3)\end{array}$ & $\begin{array}{l}\text { POINTS OF } \\
\text { WEB PAY IN } \\
\text { BANKS }\end{array}$ \\
\hline $\begin{array}{l}\text { ALPHA } \\
\text { BANK }\end{array}$ & $\mathrm{x}$ & & 4 & 2 & $\mathrm{X}$ & 0 & $\mathrm{x}$ & 3 & 3 & \\
\hline $\begin{array}{l}\text { NATIONAL } \\
\text { BANK }\end{array}$ & & $\mathrm{x}$ & 3 & 3 & $\mathrm{x}$ & 3 & $\mathrm{x}$ & 3 & 0 & $\mathrm{x}$ \\
\hline EUROBANK & $x$ & $x$ & 2 & 5 & $x$ & 2 & $\mathrm{x}$ & 3 & 3 & \\
\hline $\begin{array}{l}\text { PIRAEUS } \\
\text { BANK }\end{array}$ & & $\mathrm{x}$ & 3 & 5 & $\mathrm{X}$ & 3 & $\mathrm{x}$ & 3 & 1 & \\
\hline
\end{tabular}

Table 2 shows the evaluation of the implementation of each Bank's Web Banking for the retail segment, a bank as well as the range of payment features and services offered.

\subsection{Level of Mobile and Mobile Apps Offered}

Since Phone Banking, we have moved to the era of Mobile Banking, which one can use to process payments in two different ways: either through Mobile Browsers or through Mobile Banking, through the various mobile Applications. In mobile apps coverage, there seems to be much more to be done as it is a fuzzy landscape with stuck applications requiring additional options to install etc. Unfortunately, many do not provide the same payment range as WEB Banking. At the same time, the use of a special form of intact transaction that now exists on NFC mobiles offers another alternative for digital payment.

It should also be noted that this calibration applies not only to mobile but also to Tablets or similar devices if they do not belong to the PC category, even in the form of a laptop, as they are placed in WEB banking access by a user. Mobile smartphones come in three versions 
based on what is called their operating system and are Android, MacOS, and Windows.

Table 3. Web banking via mobile phones

\begin{tabular}{|c|c|c|c|c|c|c|c|}
\hline & \multicolumn{6}{|c|}{ Mobile banking - E banking and Applications } & \multirow[b]{2}{*}{$\begin{array}{c}\text { Innovative } \\
\text { App. }\end{array}$} \\
\hline & $\begin{array}{l}\text { Phone } \\
\text { Banking }\end{array}$ & $\begin{array}{c}\text { Android } \\
\text { App. }\end{array}$ & $\begin{array}{c}\text { Windows } \\
\text { App. }\end{array}$ & $\begin{array}{l}\text { MacO } \\
\text { S App. }\end{array}$ & $\begin{array}{l}\text { NFC } \\
\text { Pay }\end{array}$ & $\begin{array}{c}\text { Credit } \\
\text { points } \\
\text { App. }\end{array}$ & \\
\hline ALPHA BANK & $\mathrm{x}$ & $\mathrm{x}$ & & $\mathrm{x}$ & $\mathrm{x}$ & $\mathrm{x}$ & $\mathrm{x}$ \\
\hline $\begin{array}{l}\text { NATIONAL } \\
\text { BANK }\end{array}$ & $\mathrm{x}$ & $\mathrm{x}$ & & $\mathrm{x}$ & $\mathrm{x}$ & $\mathrm{x}$ & 5 \\
\hline EUROBANK & $\mathrm{x}$ & $\mathrm{x}$ & & $\mathrm{x}$ & & $\mathrm{x}$ & $\mathrm{x}$ \\
\hline PIRAEUS BANK & $\mathrm{x}$ & $\mathrm{x}$ & $\mathrm{x}$ & $\mathrm{x}$ & $\mathrm{x}$ & $\mathrm{x}$ & $\mathrm{x}$ \\
\hline
\end{tabular}

4.5 Level of Offered Security Transactions through Mobile and Web Banking

The security level is high in all Banks as well as transaction history information. One of these seems to be lagging, as there has been no reporting on Statements. In one of the Banks in question, the Cryptography Protocol is older, but this does not mean it does not provide security. Just on the days we go through 256bit encryption is widely used as less sensitive to decoding and hacking. Note that 512bit keys are already in use, but also 1024bit. The rating for this has values 0 (if it did not have some encryption) 2 if it had 128bit and 3 if it had the 256bit.

Table 4. Transaction security

\begin{tabular}{|c|c|c|c|c|c|c|c|}
\hline & \multicolumn{7}{|c|}{ Types of Transactions and Security Information } \\
\hline & \multicolumn{5}{|c|}{ Transaction Web } & \multicolumn{2}{|c|}{ Transaction update } \\
\hline & $\begin{array}{c}\text { SMART } \\
\text { BAND }\end{array}$ & TOKEN & $\begin{array}{l}\text { MOBILE } \\
\text { APPL. }\end{array}$ & SMS & $\begin{array}{c}\text { Encryption } \\
\text { level }\end{array}$ & SMS Statement & $\begin{array}{l}\text { Email } \\
\text { Statement }\end{array}$ \\
\hline $\begin{array}{l}\text { ALPHA } \\
\text { BANK }\end{array}$ & & $\mathrm{x}$ & $\mathrm{x}$ & $x$ & $\begin{array}{l}\text { Grade 5-TLS } \\
\text { Encryption } \\
256 \text { bit }\end{array}$ & $\mathrm{x}$ & $x$ \\
\hline $\begin{array}{l}\text { NATIONAL } \\
\text { BANK }\end{array}$ & $x$ & $\mathrm{x}$ & & $\mathrm{x}$ & $\begin{array}{l}\text { Grade 5-TLS } \\
\text { Encryption } \\
256 \text { bit }\end{array}$ & $x$ & $x$ \\
\hline EUROBANK & & $\mathrm{x}$ & & $\mathrm{x}$ & $\begin{array}{l}\text { Grade 5-TLS } \\
\text { Encryption } \\
256 \text { bit }\end{array}$ & & \\
\hline $\begin{array}{l}\text { PIRAEUS } \\
\text { BANK }\end{array}$ & & $x$ & & $x$ & $\begin{array}{l}\text { Grade 4-SSL- } \\
128 \text { bit }\end{array}$ & $x$ & $x$ \\
\hline
\end{tabular}

\subsection{Level of Social Networking and Other Additional Digital Channels or Facilities}

The entry of social networks into the life and daily routine of Bank customers is perhaps also a guide to expanding technology to a larger audience. With their appearance, Banks have a direct way of contacting and monitoring their clientele with various means (Likes for contests, etc.), direct relaying of new, non-costly advertising products. At the same time, technological 


\section{I Macrothink}

intervention in non-attendance at the counter is provided in various ways, such as booklet information machines or exclusive machines for bill payments and no account at the Bank. Digital Stores (Digital Spaces) are the latest achievement of Technology. Someone who has the necessary devices can go and do there without fear of trading in the environment provided by the bank without having to wait in a queue. Each of these additional benefits / services will be rated 1 degree.

Table 5. Digital facilities

\begin{tabular}{|c|c|c|c|c|c|c|c|c|c|c|c|c|}
\hline & \multicolumn{10}{|c|}{ ELECTRONIC FACILITIES - PROMOTION IN } & \multirow{3}{*}{$\begin{array}{c}\text { ELECTR } \\
\text { ONIC } \\
\text { SIGNA } \\
\text { TURE }\end{array}$} & \multirow{3}{*}{$\begin{array}{l}\text { ATM- } \\
\text { Account } \\
\text { Booklet }\end{array}$} \\
\hline & \multicolumn{5}{|c|}{ SOCIAL MEDIA } & \multirow{2}{*}{$\begin{array}{l}\text { DIGITAL } \\
\text { MULTIL } \\
\text { EVEL }\end{array}$} & \multirow[b]{2}{*}{$\begin{array}{l}\text { DIGITAL } \\
\text { PROMO } \\
\text { TIONS }\end{array}$} & \multirow{2}{*}{$\begin{array}{l}\text { TRANSA } \\
\text { CTIONS } \\
\text { POINTS }\end{array}$} & \multirow{2}{*}{$\begin{array}{c}\text { ECOLO } \\
\text { GICAL } \\
\text { FOOTP } \\
\text { RINT }\end{array}$} & \multirow{2}{*}{ ATMs } & & \\
\hline & $\begin{array}{l}\text { FACE } \\
\text { BOOK }\end{array}$ & $\begin{array}{l}\text { TWIT } \\
\text { TER }\end{array}$ & $\begin{array}{l}\text { YOU } \\
\text { TUBE }\end{array}$ & $\begin{array}{l}\text { LINKE } \\
\text { DIN }\end{array}$ & Other & & & & & & & \\
\hline $\begin{array}{l}\text { ALPHA } \\
\text { BANK }\end{array}$ & & $\mathrm{X}$ & $\mathrm{X}$ & $\mathrm{X}$ & & & $\mathrm{X}$ & $\mathrm{X}$ & $\mathrm{X}$ & & & \\
\hline $\begin{array}{l}\text { NATIONAL } \\
\text { BANK }\end{array}$ & $X$ & $X$ & $X$ & $X$ & & $X$ & $\mathrm{X}$ & $X$ & & & & \\
\hline EUROBANK & & $X$ & $\mathrm{X}$ & $X$ & & & $X$ & $X$ & $X$ & $X$ & $X$ & $X$ \\
\hline $\begin{array}{l}\text { PIRAEUS } \\
\text { BANK }\end{array}$ & $X$ & $X$ & $\mathrm{X}$ & $X$ & $X$ & $X$ & $X$ & $\mathrm{X}$ & $\mathrm{X}$ & $X$ & $\mathrm{X}$ & $\mathrm{X}$ \\
\hline
\end{tabular}

\subsection{Final Image of Calibration}

As mentioned above, the purpose of the calibration is not to highlight a winning bank, but to highlight whether they all have the same level of benefits and facilities they provide to their customers. If they have made some innovation and are keeping up with similar Banks abroad. B.C. surely the use of a smart band can help a customer segment, but the solidarity card is also an important product for another category. Useful is not the purpose of the study, but it is the purpose of the study to count them as an incentive to choose a "potential" client of the Bank.

Table 6. Final digitization image

\begin{tabular}{|l|c|c|c|c|c|c|}
\hline & & & & TRANSACTIONS & $\begin{array}{l}\text { ADDITIONAL } \\
\text { DIGITAL }\end{array}$ & TOTAL GRADES \\
\hline ALPHA BANK & 7 & 15 & 5 & 8 & 6 & 41 \\
\hline NATIONAL BANK & 6 & 16 & 10 & 8 & 7 & 47 \\
\hline EUROBANK & 5 & 21 & 4 & 5 & 8 & 43 \\
\hline PIRAEUS BANK & 5 & 20 & 7 & 6 & 12 & 50 \\
\hline
\end{tabular}

The conclusion drawn from the calibration is that the banking sector seems to follow technological developments and make the necessary changes to turn any digital achievements into its own benefit. As it turns out, the four system banks have a similar level in one way or another. It is obvious that the concrete result is a static, as technological developments are rapid, and the websites are constantly changing, adding new innovations. 
4.8 Domestic Banks Compared to the Rest of the International

The level of Greek banks does not seem to deviate from the rest of the European or international banking environment. Although there are significant differences, mainly in payments, they are due to the procedural and legislative differences between the countries that operate the Banks. If there is a difference in technological developments, this is mainly due to the implementation of technical transactions such as NFC and Mobile Banking through APPS, which are not yet mature for use in Greece. Also, the country's recession and the use of Capital Controls, where they have greatly reduced business and investment, played a key role, so banks had to give a special base to those affected by this situation, such as the preservation of liquidity to make sophisticated investments (Bank of Greece, 2017).

\section{Conclusions}

Digital Transformation seems to have been materialized to a large extent by Greek Banks, which continue to innovate in Retail Banking continuously improving their websites and customer choice options. Volume and timing of transactions has declined, banking services have grown, and consumer / customer banking seems to be familiar with the use of WEB Banking facilities.

A question that cannot be answered without a combined and further investigation is whether the development of digital banking is due solely to Digital Transformation or helped with the implementation of Capital controls.

Of great importance is the main factor that has prompted the digital era one step further for the Banks and their customers. It is important to mention that the Banking sector in Greece has gone on the same footing as banks abroad and is barely able to provide services and services, despite the adverse economic conditions.

It is noted that the evaluation of the websites of the banks presents their image as it was at the time of their research. This assessment may have been overturned as developments in this industry are constantly changing.

\section{References}

Alpha Bank. Annual Report, Year 2011, pp. 4, 15-16, 27-28, 44

Alpha Bank. Annual Report, Year 2012, pp. 4, 13-15,23-25,34,37

Alpha Bank. Annual Report, Year 2013, pp 6, 20-21, 32-35, 52

Alpha Bank. Annual Report, Year 2014, pp. 4, 16-18, 30-32, 50

Alpha Bank. Annual Report, Year 2015, pp. 5.19-20.33-36.60

Alpha Bank. Annual Report, Year 2016, pp. 4,18-19,32-36,61,58

Association of Greek Industries (SEB) and Accenture (2017). Study on Digital 
Transformation in Greek Enterprises, May

Bank of Greece (2017). Overview of the Financial System, ISSN 2529-0681

Digital Transformation, https://en.wikipedia.org/wiki/Digital_transformation

Drinkwater Doug (2016). 10 innovative technologies changing the face of retail banking, Internet of Business. Available at:

https://internetofbusiness.com/10-technologies-changing-retail-banking/

Eurobank. Annual Report, Year 2011, pp. 3, 14, 29

Eurobank. Annual Report, Year 2012, pp. 15, 19-20, 31, 53

Eurobank. Annual Report, Year 2013, pp. 7, 18-19, 30, 49

Eurobank. Annual Report, Year 2014, pp. 5, 18, 25-27, 33, 58

Eurobank. Annual Report, Year 2015, pp. 6, 8, 10, 12, 15, 21, 30-32, 72

Eurobank. Annual Report, Year 2016, pp. 8, 12, 27, 37, 39, 46-47, 55, 57-58, 65

http://www.citethisforme.com/topic-ideas/economics/FINTECH\%20AND\%20BANKING-41 473361

http://www.seidor.com/content/seidor-com/en/digital/metodologia.html)

National Bank of Greece. Annual Report, Year 2014, p.2, 23-24, 32-34, 74

National Bank of Greece. Annual Report, Year 2015, p.2, 25-26, 34-36, 79

National Bank of Greece. Annual Report, Year 2016, p.2, 28-29, 36, 39-41, 80

Papadimitriou Georgios (2018) Digital banking: The Next Bet, Economic Kathimerini Newspaper (Issue 18-03-2018), p. 8

Piraeus Bank. Annual Report, Year 2011, pp 9, 41, 49-51, 73-80, 91

Piraeus Bank. Annual Report, Year 2012, pp. 14-15, 52, 61-64, 91-100, 112-114

Piraeus Bank. Annual Report, Year 2013, pp. 15, 48, 59-61, 94-100, 126-127

Piraeus Bank. Annual Report, Year 2014, pp. 21, 66, 71-72, 84-87, 90-91, 120-137, 153-154

Piraeus Bank. Annual Report, Year 2015, pages 32, 51-53, 67-70, 74, 93-102, 122

Piraeus Bank. Annual Report, Year 2016, pp. 40, 61, 65, 66, 78-82, 111-126, 133, 148

Price Water House Cooper, Pwc (2017) Retail Banking 2020 - Evolution or Revolution? pp. 1-44. Available at:

Wikipedia Authentication: https://en.wikipedia.org/wiki/Authentication)

Wikipedia Cryptography: https://en.wikipedia.org/wiki/Cryptography 


\section{Copyright}

Copyright for this article is retained by the author(s), with first publication rights granted to the journal.

This is an open-access article distributed under the terms and conditions of the Creative Commons Attribution license (http://creativecommons.org/licenses/by/4.0/). 